\title{
ANALISIS KEDAULATAN PANGAN PADA KOMUNITAS ADAT CIREUNDEU
}

\section{Analysis of Food Sovereignty in Cireundeu Adat Community}

\author{
Roni Fajar Santoso*) dan Sriwulan Ferindian Falatehan
}

Departemen Sains Komunikasi dan Pengembangan Masyarakat, Fakultas Ekologi Manusia, Institut Pertanian Bogor, Darmaga Bogor 16680, Indonesia

${ }^{*}$ E-mail: roniskpm51@gmail.com

\begin{abstract}
Food sovereignty is the right of every person, society, and state to access and control productive resources and control their own food systems according to the ecological, social, economic and cultural conditions of each. In this study, food sovereignty in the household is seen from the authority in determining the agricultural system and fulfillment practices in production; storage and distribution of products; food consumption choices; and management of knowledge and patenting of seeds. The assumption that can underlie food sovereignty is that individuals have a strong sense of community so they want to be involved in the food institutional in their community. This study aims to analyze food sovereignty level in households of Cireundeu Adat Community and analyze the relationship between the sense of community level and food sovereignty level by testing construct validity. The research activity was carried out from July to October 2018 using a quantitative approach with survey techniques. The results showed that the level of food sovereignty in Cireundeu Adat Community was in the Medium category with the authority possessed in the Tokenism category and the practice of fulfilling the elements of food sovereignty in the Medium category. The results of the construct identification validity using the correlation Rank-Spearman test show that there is no relationship between sense of community and food sovereignty which is indicated by a value of $\alpha>0.05$ with a correlation coefficient of 0.115 . This shows that a sense of community is not a major trigger in building food sovereignty.
\end{abstract}

Keywords: Adat community, Food sovereignty, Sense of community.

\begin{abstract}
ABSTRAK
Kedaulatan pangan merupakan hak setiap orang, masyarakat, dan negara untuk mengakses dan menguasai sumber daya produktif dan menguasai sistem pangannya sendiri sesuai dengan kondisi ekologi, sosial, ekonomi dan budaya masing-masing. Dalam studi ini, kedaulatan pangan dalam rumah tangga dilihat dari kewenangannya dalam menentukan sistem pertanian dan praktik pemenuhan dalam berproduksi; penyimpanan dan distribusi produk; pilihan konsumsi makanan; dan pengelolaan pengetahuan dan pematenan benih. Asumsi yang mendasari kedaulatan pangan adalah individu memiliki rasa kebersamaan yang kuat sehingga ingin terlibat dalam kelembagaan pangan di komunitasnya. Penelitian ini bertujuan untuk menganalisis tingkat kedaulatan pangan dalam rumah tangga Masyarakat Adat Cireundeu dan menganalisis hubungan antara rasa tingkat masyarakat dan tingkat kedaulatan pangan dengan menguji validitas konstruk. Kegiatan penelitian dilaksanakan pada bulan Juli hingga Oktober 2018 dengan menggunakan pendekatan kuantitatif dengan teknik survei. Hasil penelitian menunjukkan bahwa tingkat kedaulatan pangan pada Masyarakat Adat Cireundeu berada pada kategori Sedang dengan kewenangan yang dimiliki pada kategori Tokenisme dan praktik pemenuhan unsur kedaulatan pangan pada kategori Sedang. Hasil validitas identifikasi konstruk menggunakan uji korelasi RankSpearman menunjukkan bahwa tidak ada hubungan antara rasa kebersamaan dengan kedaulatan pangan yang ditunjukkan dengan nilai $\alpha>0,05$ dengan koefisien korelasi 0,115 . Hal ini menunjukkan bahwa rasa kebersamaan bukanlah pemicu utama dalam membangun kedaulatan pangan.
\end{abstract}

Kata kunci: Kedaulatan pangan, Masyarakat adat, Rasa kebersamaan. 


\section{PENDAHULUAN}

Pangan merupakan kebutuhan utama manusia untuk melangsungkan kehidupannya, ketika laju pertumbuhan manusia tidak diimbangi dengan pemenuhan pangan bagi manusia, maka akan menyebabkan masalah pangan (Yuwono et al. 2011). Indonesia sudah memperhatikan urusan pangan dengan adanya Undang- Undang No 18 tahun 2012 tentang pangan yang menjadi solusi akan permasalahan pangan yaitu dengan pendekatan kedaulatan pangan dan ketahanan pangan. Perbedaan mengenai ketahanan pangan dengan kedaulatan pangan adalah lebih menitikberatkan pada ketersediaan pangan tanpa memperdulikan asal dan pihak yang memproduksi pangan tersebut. Kedaulatan pangan lebih menitikberatkan pada kemampuan secara mandiri masyarakat suatu wilayah akan pangan, perlindungan pada petani, dan ekosistem lokal. Kedua konsep ini dapat dipandang berlawanan tetapi dapat juga sejalan, karena kedaulatan pangan dapat dipandang melengkapi ketahanan pangan sebagai prasyarat untuk mencapai tujuan kedaulatan pangan (Yuwono et al. 2011). Kedaulatan pangan menurut Yuwono et al. (2011) adalah hak setiap orang, masyarakat, dan negara untuk mengakses dan mengontrol aneka sumberdaya produktif serta menentukan dan mengendalikan sistem pangan sendiri sesuai keadaan ekologi, sosial, ekonomi, dan budaya masing masing. Elemen dari kedaulatan pangan meliputi: (1) Produksi pangan untuk pasar domestik dan lokal; (2) Memanfaatkan usahatani petani kecil dan keluarga yang agro-ekologis; (3) Menjamin akses tanah dan sumber-sumber daya yang vital; (4) Menjamin terciptanya harga yang adil; (5) Menghormati peran wanita dalam produksi pangan; (6) Mendorong kontrol komunitas atas sumberdaya produktif, dan (7) Melindungi benih dari pematenan (Saleh 2011). Namun Andreas dalam Kompas.com (2013) menyatakan bahwa enam pilar yang belum dipenuhi dalam kedaulatan pangan yaitu: (1) Hak atas pangan namun masih adanya sebagian masyarakat yang kelaparan di Indonesia, misalnya di Nusa Tenggara Timur; (2) Reforma agraria karena masih ada lebih dari 65\% keluarga petani di Jawa dan luar Jawa yang tidak memiliki lahan; (3) Akses petani terhadap sumber daya air, genetik, dan sumberdaya alam namun masih ada 50\% jaringan irigasi strategis nasional yang rusak di Jawa; (4) Produksi pertanian yang agroekologi yang berpusat di komunitas dan keluarga; (5) Perlindungan petani dari perdagangan pangan internasional yang tidak adil; dan (6) Demokrasi sehingga petani kecil mempunyai hak untuk menetapkan kebijakan pertanian pada semua level.

Saleh (2011) menyatakan bahwa usaha mencapai kedaulatan pangan yang hakiki perlu memperhatikan kelembagaan yang berkembang di masyarakat terutama yang berkaitan dengan pengaturan pangan. Pihak-pihak yang terkait, seperti pemerintah, dapat berinteraksi dalam kelembagaan untuk bersama-sama masyarakat mencari solusi atas masalah yang muncul di masyarakat. Berdasarkan data Badan Ketahanan Pangan Daerah (2013) bahwa Kota Cimahi yang memiliki tingkat ketahanan pangan yang tinggi ketiga $(49,37)$ dan tingkat kerawanan pangan yang rendah ketiga $(5,79)$ di Jawa Barat. Hal tersebut menjadi dasar ketertarikan peneliti untuk meneliti mengenai tingkat kedaulatan pangan di salah satu daerah di Kota Cimahi, terlebih juga memiliki kampung adat yang khas dengan kearifan lokalnya yaitu Kampung Adat Cireundeu berupa kebiasaan mengonsumsi beras singkong (Rasi) dibandingkan beras padi. Oleh karena itu, Komunitas Adat Cireundeu dapat dikategorikan menampilkan perilaku kolektif yang berdaulat atas sistem pangannya sendiri baik untuk produksi dan konsumsinya. Mereka memiliki kearifan lokal daerah tersebut dengan praktek menanam singkong maupun jenis tanaman lainnya yang ada di komunitas tersebut, seperti sayuran. Kebiasaan ini tidak pernah berubah walaupun telah banyak perubahan kebijakan pangan setiap tahunnya seperti pergantian varietas benih singkong yang ditanam.

Oleh karena itu, penting untuk meneliti tentang bagaimana kedaulatan pangan di Komunitas Adat Cireundeu? Tujuan dari penelitian ini yaitu untuk Menganalisis tingkat kedaulatan pangan pada rumah tangga, menganalisis tingkat rasa memiliki komunitas pada anggota pada Komunitas Adat Cireundeu, dan Menganalisis validitas konstruk rasa memiliki komunitas pada hubungan tingkat rasa memiliki komunitas terhadap tingkat kedaulatan pangan pada Komunitas Adat Cireundeu. 


\section{PENDEKATAN TEORITIS}

\section{Kedaulatan Pangan}

Konsep kedaulatan pangan telah telah berkembang di dunia internasional maupun di Indonesia. Para pencetus konsep ini berada dalam organisasi La Via Campesina. Menurut La Via Campesina (2006) dalam Syahyuti et al. (2015), kedaulatan pangan adalah hak setiap bangsa untuk mempertahankan dan mengembangkan kemampuan sendiri untuk menghasilkan pangan dasar dengan menghormati keragaman budaya dan sistem produksinya.

Syahyuti et al. (2015) menambahkan bahwa konsep kedaulatan pangan dapat dirumuskan menjadi dua level yang berbeda yaitu level negara dan level rumah tangga. Level negara disebutkan bahwa pendekatan kedaulatan pangan mesti sejalan dengan program agribisnis. Level rumah tangga yaitu dapat diukur dari kedaulatan petani terhadap lahan, air, benih, pupuk dan obat-obatan, sistem usaha pertanian (teknologi), hasil produksi, serta kedaulatan dalam mengkonsumsi. Hal berbeda disampaikan oleh Saleh (2011) mengenai kedaulatan pangan yaitu kedaulatan pangan mempunyai fokus pada beberapa elemen kunci. Elemen tersebut meliputi: (1) Produksi pangan untuk pasar domestik dan lokal; (2) Memanfaatkan usahatani petani kecil dan keluarga yang agro-ekologis; (3) Menjamin akses tanah dan sumber-sumber daya yang vital; (4) Menjamin terciptanya harga yang adil; (5) Menghormati peran wanita dalam produksi pangan; (6) Mendorong kontrol komunitas atas sumberdaya produktif; dan (7) Melindungi benih dari pematenan.

Menurut definisi yang diungkapkan oleh La Via Campesina (2006) Syahyuti et al. (2015) mengenai hak menentukan pangan sendiri dapat diartikan bahwa setiap orang memiliki kewenangan dalam menentukan pangan untuk dirinya sendiri tidak ditentukan oleh orang lain atau pihak manapun. Untuk mengukur kewenangan seseorang baik dalam ruang lingkup individu atau rumah tangga, dapat menggunakan tangga partisipasi menurut Arnstein (1969) dalam Duadji (2013).

Tingkat partisipasi masyarakat yang dikemukakan oleh Arnstein (1969) dalam Duadji (2013) menggunakan tangga partisipasi masyarakat atau ladder of citizen participation. Menurut konsep ini terdapat tiga derajat partisipasi yang kemudian diperinci ke dalam delapan tahapan anak tangga partisipasi, yaitu:

8.

7.

Kontrol warga negara didelegasikan

Partisipasi

Aktif

6.

Kemitraan

5.

Menenangkan

4.

Konsultasi

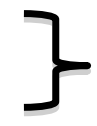

3. Menginformasikan

2.

Terapi

1.

Manipulasi

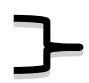

Tokenisme

Non-

Partisipasi 
Masing-masing dari delapan tahapan anak tangga partisipasi ini akan dijelaskan sebagai berikut: (1) Manipulasi yaitu partisipasi hanya sebagai formalitas semata dan masyarakat diikutsertakan sebagai "stampel karet" dalam badan penasihat; (2) Terapi yaitu ketidakberdayaan masyarakat dianggap sebagai penyakit sehingga keterlibatan masyarakat hanya bertujuan untuk menghilangkan "luka"-nya saja dan bukan menemukan penyebab "luka"-nya; (3) Menginformasikan yaitu pemberian informasi kepada masyarakat akan hak, tanggungjawab, dan pilihan mereka. Namun, seringkali pemberian informasi ini bersifat satu arah sehingga masyarakat tidak memiliki kesempatan dan kekuatan untuk melakukan negosiasi; (4) Konsultasi yaitu bentuk partisipasi semu yakni masyarakat mulai diminta pendapatnya melalui forum jajak pendapat dan pertemuan warga. Hanya saja pemegang kekuasaan tetap yang mengambil keputusan; (5) Menenangkan yaitu masyarakat sudah memiliki beberapa pengaruh dengan memberi masukan dan mengusulkan rencana, tetapi keputusan tetap dipegang oleh pemangku kekuasaan; (6) Kemitraaan yaitu kekuasaan disalurkan melalui negosiasi antara pemegang kekuasaan dengan masyarakat. Mereka sepakat untuk sama-sama memikul tanggungjawab dalam perencanaan dan pengambilan keputusan; (7) Kekuasaan yang didelegasikan yaitu tingkatan ini masyarakat menduduki mayoritas kursi sehingga memiliki kekuasaan dalam menentukan suatu keputusan; dan (8) Kontrol warga negara yaitu tingkatan partisipasi terakhir dimana masyarakat menginginkan adanya jaminan bahwa kewenangan untuk mengatur program dan kelembagaan sepenuhnya diberikan kepada mereka.

\section{Komunitas Adat}

Menurut Siregar (2002) komunitas adat adalah komunitas yang hidup berdasarkan asal - usul leluhur, di atas wilayah adat, yang memiliki kedaulatan atas tanah dan kekayaan alam, kehidupan sosial yang diatur oleh hukum adat, dan lembaga adat yang mengelola keberlangsungan kehidupan masyarakatnya. Hal ini seperti yang disampaikan oleh Aliansi Masyarakat Adat Nusantara (AMAN) bahwa masyarakat adat (Tishaeni 2010) yaitu: (1) Sekelompok orang dengan identitas budaya yang sama; (2) Sekelompok orang yang saling berbagi sistem pengetahuan. Ciri ini terkait dengan sistem pengetahuan yang dibagikan (sharing knowledge) yang bermuara pada kesamaan dalam sosialisasi dan internalisasi kebudayaan; (3) Sekelompok orang yang tinggal di wilayah yang sama; (4) Sekelompok orang yang memiliki sistem hukum yang khas dan tata kepengurusan kehidupan bersama.

Komunitas adat sendiri sebagian besar tinggal di pedesaan dan di sekitar hutan. Memanfaatkan sumbedaya alam yang ada untuk memenuhi kebutuhan sehari- hari dengan terus menjaga kelestariannya (Nugrahayuningtyas 2017). Hal ini berarti komunitas adat atau masyarakat adat memiliki cara dan aturan sendiri dalam pemenuhan kebutuhan pangan masyarakatnya.

Lingkungan pemukiman komunitas adat terpencil pada umumnya dikelompokkan menjadi empat jenis (Tishaeni 2010), yaitu: (1) KAT yang tinggal di dataran tinggi dan atau daerah pegunungan; (2) KAT yang tinggal di daerah pedalaman dan atau daerah perbatasan; (3) KAT yang tinggal di dataran rendah dan atau daerah rawa; dan (4) KAT yang tinggal diatas perahu dan atau daerah pantai.

Habitat tersebut sangat berhubungan langsung dengan sistem mata pencaharian komunitas adat terpencil yaitu merupakan perwujudan adaptasi aktif komunitas yang bersangkutan terhadap lingkungan hidupnya seperti berburu dan meramu, berladang berpindah dan pencari ikan atau kombinasi di antara ketiganya (Tishaeni 2010).

\section{Kelembagaan Pangan}

Menurut Sumardjo (2003) dalam Saleh (2011) kelembagaan pangan masyarakat sebagai segala bentuk pengaturan atau keteraturan perilaku masyarakat dalam memenuhi kebutuhan pangan di masyarakat yang telah menjadi acuan dalam bertindak, karena di dalamnya terkandung nilai, norma, penggunaan atau pemanfaatan, pemeliharaan sarana dan prasarana pendukungnya, serta cara-cara perpola pengendalian sosial agar kelembagaan tersebut senantiasa terjaga dengan efektif sebagai wahana memenuhi kebutuhan masyarakat. 
Saleh (2011) mengungkapkan untuk mengukur kelembagaan pangan masyarakat dapat dilihat dari aspek produksi, penyimpanan, dan distribusi, yaitu: (1) Produksi yaitu upaya seseorang atau petani dalam mengelola budidaya pertanian atau semua komoditi bahan makanan yang diperoleh rumahtangga dari hasil usaha pertanian; (2) Penyimpanan atau lumbung pangan adalah suatu sistem kelembagaan penyedia bahan pangan dan bahan-bahan lainnya yang bertujuan meningkatkan kesejahteraan penduduk pedesaan, terutama menanggulangi kerawanan pangan; dan (3) Distribusi adalah sistem kelembagaan pangan yang dilakukan dengan mendistribusikan atau menyalurkan bahan pokok atau olahan pangan kepada pihak luar penyedia bahan pokok atau olahan pangan.

Menurut Yuniarti (2013) menyebutkan bahwa kelembagaan yang keberlanjutan harus dinilai menurut kemampuan lembaga untuk berkoordinasi pada interaksi manusia dalam rangka mencapai tujuan kelembagaan yang berkelanjutan.

Nasdian (2014) mengatakan bahwa untuk mengukur tingkat keberlanjutan kelembagaan komunitas lokal dapat dianalisis dari faktor-faktor internal dan eksternal sebagai faktor-faktor penentu yang mempengaruhi keberlanjutan kelembagaan komunitas lokal. Faktor-faktor internal tersebut mencakup (1) kepemimpinan, (2) pendidikan anggota, (3) aturan tertulis, (4) aturan tidak tertulis, (5) ukuran kelembagaan, (6) usia kelembagaan, (7) kecukupan anggaran, dan (8) proses pendirian kelembagaan. Faktor-faktor eksternal yang mempengaruhi keberlanjutan kelembagaan komunitas lokal adalah (a) intervensi pemerintah yang berdampak positif, (b) intervensi pemerintah yang berdampak negatif, (c) Ketersediaan sarana dan prasarana umum, dan (a) jejaring kerjasama antar kelembagaan.

\section{Rasa Memiliki Komunitas}

Suatu komunitas memiliki ikatan hubungan emosional yang disebut rasa memiliki komunitas atau Sense of Community (SOC) antar anggotanya. Suatu ikatan emosional di antara mereka tersebut untuk berbagi kebutuhan mereka dan saling terpenuhi satu sama lain. Menurut McMillan dan Chavis (1986), seseorang dikatakan memiliki rasa memiliki komunitas ketika mereka merasakan empat elemen dalam sebuah komunitas, yaitu: (1) Keanggotaan adalah perasaan bahwa seseorang telah menginvestasikan diri sendiri untuk menjadi anggota dalam sebuah komunitas. Keanggotaan dalam sebuah komunitas memiliki batasan, keamanan emosional, rasa memiliki dan identifikasi, dan memiliki simbol umum dalam komunitas; (2) Pengaruh adalah kekuatan yang dimiliki individu untuk mempengaruhi anggota lain dan kekuatan komunitas untuk mempengaruhi individu; (3) Integrasi dan pemenuhan kebutuhan adalah perasaan bahwa kebutuhan anggota akan dipenuhi oleh sumber daya yang diterima melalui keanggotaan mereka dalam kelompok; dan (4) Berbagi hubungan emosional adalah suatu komunitas yang terbentuk dari interaksi positif, berbagi cerita dan pengalaman yang dilakukan bersama. Semakin banyak orang berinteraksi, semakin besar kemungkinan mereka membentuk hubungan yang erat, yang kemudian mengarah keikatan yang lebih kuat.

Khusairi et al. (2017) mengatakan bahwa masyarakat yang memiliki rasa memiliki komunitas yang tinggi akan ikut berpartisipasi dalam bentuk memberikan dukungan sosial di masyarakat ataupun berperan aktif dan hadir dalam memberikan kontribusi di masyarakat. Partisipasi dan interaksi antar warga yang tinggi membuat kehidupan sosial warga lebih sejahtera serta pengembangan pariwisata pun dapat menjadi lebih baik. Pendapat lain juga diungkapkan oleh Falatehan (2017) yang menemukan bahwa partispasi masyarakat dipengaruhi oleh faktor rasa memiliki rasa komunitas. Rasa memiliki komunitas ini lebih dirasakan oleh masyarakat yang cakupannya kecil yaitu di tingkat RT dan RW daripada yang cakupannya tingkat kampung. Pada tingkat ini, rasa memiliki komunitas pada tingkat RT lebih tinggi daripada pada tingkat RW. Falatehan (2017) juga menemukan faktor yang dapat memprediksi partisipasi dalam program pemeritah adalah rasa memiliki komunitas dan lama tinggal masyarakat dalam suatu masyarakat.

\section{Validitas}

Anastasi dan Urbina (1997) menyatakan bahawa validitas suatu tes menunjukkan apa yang diukur oleh sebuah alat tes dan seberapa baik alat tersebut dapat mengukur apa yang hendak diukur. Terdapat tiga prosedur untuk menguji validitas yaitu deskripsi isi, hubungan dengan kriteria lainnya, dan 
identifikasi konstruk. Prosedur identifikasi konstruk yang terdiri dari teknik: a) perkembangan menurut perkembangan; b) korelasi dengan tes lain; c) analisis faktor; dan d) konsistensi internal. Dalam penelitian ini akan menggunakan Prosedur identifikasi konstruk dengan teknik korelasi dengan tes lain. 


\section{PENDEKATAN LAPANG.}

\section{Metode Penelitian}

Metode yang dilakukan dalam penelitian ini adalah metode kuantitatif yang didukung dengan data kualitatif. Data kuantitaif diperoleh menggunakan instrumen penelitian berupa kuesioner, sedangkan untuk data kualitatif diperoleh dari wawancara mendalam kepada informan menggunakan panduan pertanyaan, observasi dan pengecekkan kembali jawaban responden.

\section{Lokasi dan Waktu Penelitian}

Penelitian ini dilakukan di Kampung Adat Cireundeu, Kelurahan Leuwigajah, Kecamatan Cimahi Selatan, Kota Cimahi. Pemilihan lokasi dilakukan secara sengaja (purposive) karena beberapa pertimbangan yaitu: (1) Kampung Adat Cireundeu menentukan konsumsi pangan mereka secara mandiri tidak tergantung oleh kebijakan pemerintah seperti mengkonsumsi beras padi, akan tetapi Kampung Adat Cireundeu sendiri mengonsumsi Beras Singkong (Rasi) sebagai pangan pokok mereka. (2) Kebiasaan ini telah dilakukan sejak lama dan pada tahun 2018, Kampung Adat Cireundeu memperingati 100 tahun akan pelestraian budaya mereka Penelitian dimulai dari bulan April 2018 Februari 2019.

\section{Teknik Penentuan Responden dan Informan}

Populas penelitian ini adalah rumah tangga di wilayah RW 10 yaitu RT 02, RT 03, dan RT 05 Kampung Adat Cireundeu. Penentuan populasi memiliki pertimbangan bahwa menurut Abah Widi masyarakat Kampung Adat Cireundeu yang mengonsumsi Beras Singkong (Rasi) terdapat pada RT 02, RT 03, dan beberapa orang yang terdapat pada RT 05 .

Dalam penelitian ini jumlah responden yang akan diambil adalah seluruh rumah tangga masyarakat adat Kampung Adat Cireundeu yang berprofesi sebagai petani yang memiliki dan menguasai lahan pertanian baik milik sendiri maupun milik pemerintah yaitu 30 rumah tangga dari 56 rumah tangga yang terbagi dalam RT 2, RT 3, dan RT 05. Pemilihan responden dalam penelitian ini dilakukan secara kluster (cluster sampling) yaitu dengan membagi populasi kedalam beberapa lapisan-lapisan (strata) yang seragam dan dari setiap strata akan diambil sampel secara acak (Effendi dan Tukiran 2012).

Selain responden, terdapat informan yang menjadi sumber data penelitian yang terdiri atas Ketua Adat Kampung Adat Cireundeu, Tokoh-tokoh Adat Kampung Adat Cireundeu, Ketua RW, Ketua RT 02 dan 03, Pegawai Pemerintah Kelurahan Leuwigajah, dan pihak terkait lainnya. Pemilihan informan dilakukan secara purposive dengan alasan informan yang dipilih tersebut merupakan informan yang mengetahui dan memahami mengenai sejarah, adat istiadat, kelembagaan pangan di Kampung Adat Cireundeu.

\section{Teknik Pengumpulan Data}

Data yang digunakan dalam penelitian ini terdiri atas data primer dan data sekunder. Data primer merupakan data yang didapatkan langsung di lapangan dengan cara observasi, pengecekkan kembali jawaban responden, dan wawancara mendalam yang dilakukan peneliti kepada responden dan informan. Data sekunder diperoleh dari dokumen-dokumen tertulis dan internet berupa data hasil penelitian akademisi terdahulu serta informasi umum terkait dengan Kampung Adat Cireundeu. Data kuantitatif dikumpulkan dengan cara observasi dan sensus melalui instrumen kuesioner. Data kualitatif didapatkan melalui pengamatan langsung, pengecekkan kembali jawaban responden, dan wawancara mendalam menggunakan pedoman pertanyaan kepada para informan, yaitu Ketua Adat Kampung Adat Cireundeu, Tokoh-tokoh Adat Kampung Adat Cireundeu, Ketua RW, Ketua RT 02, 03, dan 05, Pegawai Pemerintah Kelurahan Leuwigajah, dan pihak terkait lainnya..

\section{Teknik Pengolahan dan Analisis Data}

Penelitian ini memiliki dua jenis data primer yang diolah dan dianalisis yaitu data kuantitatif dan data kualitatif. Data kuantitatif dari kuesioner yang telah terkumpul diolah secara statistik menggunakan 
SPSS for Windows versi 21.0 dan Microsoft Excel 2010. Program Microsoft Excel 2010 digunakan pada tahap pengkodean data, yakni seluruh data kuantitatif yang didapat dari jawaban kuesioner secara lengkap dan per variabel dimasukkan kedalam program Microsoft Excel 2010. Tahap pengolahan data pada penelitian ini dianalisis dan diolah menggunakan beberapa teknik, yakni tabel frekuensi, tabel tabulasi silang, dan uji korelasi Rank Spearman. Uji korelasi Rank Spearman, bertujuan menganalisis ada tidaknya hubungan antardua variabel yang minimal berskala ordinal dan bertujuan memperkuat kesimpulan dari analisis tabulasi silang. Ketentuan hipotesis diterima atau dikatakan terdapat hubungan, apabila nilai signifikan hitung (sig-2 tailed) lebih kecil dari 0,1;0,05 dan atau 0,01. Adapun variabel-variabel yang dianalisis dan diuji adalah variabel rasa memiliki komunitas (keanggotaan, pengaruh, integrasi dan pemenuhan kebutuhan, serta berbagi pengalaman bersama) dan variabel tingkat kedaulatan pangan masyarakat Kampung Adat Cireundeu yang dilihat dari aspek kewenangan dan aspek praktik pemenuhan elemen kedaulatan pangan meliputi kedaulatan pangan produksi, penyimpanan dan distribusi hasil produksi, pilihan pangan konsumsi pangan, dan pengelolaan pengetahuan serta pematenan benih.

Data kualitatif yang diperoleh dari observasi dan wawancara mendalam dengan informan disajikan secara deskriptif guna mendukung data kuantitatif. Analisis data kualitatif disajikan dalam bentuk narasi maupun kutipan yang pada akhirnya seluruh hasil penelitian dituliskan dalam laporan skripsi. Data kualitatif dianalisis melalui tiga tahap yaitu reduksi data, penyajian data dan verifikasi. Tahap proses reduksi data, dimulai dari pemilihan dan penyederhanaan data hasil observasi dan wawancara mendalam berupa catatan lapang, rekaman audio, dan dokumen pendukung lainnya. Tujuan reduksi data ini adalah untuk mempertajam, menggolongkan, mengarahkan, dan membuang data yang tidak perlu. Tahap penyajian data, dimulai dengan menyusun segala informasi dan data yang diperoleh menjadi serangkaian kalimat yang mudah dibaca ke dalam sebuah laporan. Tahap verifikasi merupakan tahap terakhir berupa penarikan kesimpulan dari data yang diperoleh pada tahap sebelumnya untuk mendukung data kuantitatif.

\section{HASIL DAN PEMBAHASAN}

\section{Karakteristik Responden}

Survei yang dilakukan dalam penelitian ini mengambil responden sebanyak 30 orang yang terdiri dari 26 orang $(86.66 \%)$ berjenis kelamin laki-laki dan 3 orang $(13.33 \%)$ berjenis kelamin perempuan. Responden merupakan petani di Kampung Adat Cireundeu yang didominasi oleh orang dengan kategori dewasa tua (>56 tahun) yaitu sebanyak 70\%, kategori dewasa menengah (30-55 tahun) yaitu sebesar $30 \%$. Sebaran tingkat pendidikan responden masyarakat Kampung Adat Cireundeu didominasi oleh tingkat tamat Sekolah Dasar (SD) karena kemampuan dalam mengakses pendidikan pada masyarakat Kampung Adat Cireundeu hanya sampai tingkat SD atau Sekolah Rakyat (SR) terbatas.

Walaupun secara umum masyarakat Kampung Adat Cireundeu memiliki mata pencaharian mengenai sebaagai petani, akan tetapi terdapat beberapa mata pencaharian tambahan yang dilakukan oleh responden untuk menambah penghasilan rumah tangga mereka seperti peternak (kambing dan domba), buruh pabrik, wirausaha, pedagang, dan lain-lain.

\section{Tingkat Kedaulatan Pangan Kampung Adat Cireundeu}

Kedaulatan pangan pada Kampung Adat Cireundeu dilihat dari tingkat kewenangan dan tingkat pemenuhan praktik elemen kedaulatan pangan yaitu meliputi tingkat kedaulatan pangan pada produksi, penyimpanan dan distribusi, pilihan konsumsi pangan, serta pengelolaan pengetahuan dan pematenan benih. Hal ini didukung dengan hasil uji statistik korelasi Rank Spearman antara kewenangan dan praktek pemenuhan elemen kedaulatan pangan sebesar $0.534(\alpha<0.05)$ yang artinya kedua aspek tersebut berhubungan secara positif dan signifikan dalam menyusun Kedaulatan Pangan. 
Tabel 1 Jumlah dan persentase responden berdasarkan tingkat kedaulatan pangan Kampung Adat Cireundeu, 2018

\begin{tabular}{crr}
\hline $\begin{array}{c}\text { Tingkat } \\
\text { Kedaulatan } \\
\text { Pangan }\end{array}$ & $\begin{array}{r}\text { Jumlah } \\
\text { (Orang) }\end{array}$ & $\begin{array}{c}\text { Persentase } \\
(\%)\end{array}$ \\
\hline Rendah & 1 & 3.33 \\
Sedang & 19 & 63.33 \\
Tinggi & 10 & 36.67 \\
\hline Total & 30 & 100.00 \\
\hline
\end{tabular}

Dari Tabel 1 dapat dilihat bahwa sebanyak 63.33\% responden memiliki tingkat kedaulatan pangan masyarakat Adat Cireundeu berada padatingkat Sedang. Elemen yang paling kuat menyumbang kedaulatan pangan komunitas ini yaitu Penyimpangan dan distribusi, kemudian disusul oleh elemen Produksi, Pilihan konsumsi pangan, dan Pengelolaan pengetahuan serta pematenan benih. Kampung Adat Cireundeu memiliki tingkat kewenangan dalam kategori Tokenisme dalam kelembagaan pangannya dan telah melakukan praktik pertanian yang dapat mewujudkan kedaulatan pangan.

Tingkat kedaulatan pangan dalam hal produksi, berada pada kategori Sedang. Hal ini menunjukkan bahwa secara produksi pertanian, masyarakat memiliki kewenangan secara Tokenism dan telah melakukan praktik pertanian dalam hal produksi bahan pangan pokok dan tambahan secara mandiri untuk mewujudkan kedaulatan. Suatu wilayah dapat dikatakan sebagai wilayah yang berkedaulatan pangan jika dalam pengelolaan pertaniannya menggunakan pertanian agro-ekologis yaitu pelaksanaan produksi pertanian yang memperhatian faktor ekologi setempat. Hal ini dapat dilihat dari faktor kedaulatan atas lahan, pupuk, obat-obatan, air, dan sistem pertanian. Kampung Adat Cireundeu ratarata memiliki lahan pertanian sendiri dengan pengelolaan yang dilakukan oleh masing-masing. Sebagian dari petani, mengelola lahan pertanian yang mereka milik sendiri ataupun dari tanah pemerintah bekas tanah longsor. Pupuk yang digunakan dalam proses budidaya pertanian adalah pupuk organik (kotoran kambing atau domba) dan pupuk anorganik (urea). Pupuk urea yang digunakan untuk peningkatan umbi singkong ini hanya sebanyak setengah sendok untuk setiap tanaman per sekali tanam. Hal ini dilakukan untuk menjaga kesuburan tanah. Hal unik yang dilakukan oleh masyarakat dalam budidaya pertanian adalah tidak pernah menggunakan pestisida, obat pengendalian hama, dan air. Keputusan ini dilakukan atas dasar yang kuat yaitu penggunaan pestisida dan pengendalian hama tanaman merupakan tindakan yang dapat merusak alam. Lain halnya dengan air, masyarakat yang tidak pernah menyiram tanaman budidayanya dalam pengelolaannya karena mereka meyakini bahwa di dalam lahan pertanian mereka masih terdapat air yang dapat mencukupi tanaman mereka. Dasar ini diyakini karena selama ini pengelolaan hutan mereka menjadi 3 wilayah (hutan tutupan, hutan reboisasi, hutan pertanian). Kebiasaan ini telah dilakukan dari pendahulu mereka dan terus dipertahankan hingga sampai saat ini.

Sistem pertanian yang dilakukan oleh sebagian responden adalah sistem pertanian terasering dan sistem pertanian tumpang sari terasering. Hal ini dilakukan agar air hujan dapat terjaga di lahan pertanian tersebut serta tetap menjaga kondisi lahan pertanian tetap baik dan tidak tererosi akibat hujan serta memanfaatkan lahan pertanian dengan menanam lebih dari satu jenis tanaman. Selanjutnya tingkat kedaulatan pangan dalam hal penyimpanan dan distribusi hasil pertanian berada pada kategori Tinggi dengan kewenangan masyarakat yang Partisipasi Aktif dan praktek pemenuhan elemen kedaulatan pangan yang Sedang.

Masyarakat biasanya melakukan penyimpanan bahan pokok singkong di dalam rumah. Masyarakat yang melakukan penyimpanan di luar rumah, biasanya disimpan di rumah kayu atau di gudang penyimpanan di luar rumah. Mayoritas masyarakat mengetahui tata cara penyimpanan bahan pangan pokok singkong dan komoditas lain agar bahan pangan tersebut bertahan hingga berbulan-bulan. Beberapa masyarakat belum mengetahui secara tepat cara dalam penyimpanan dan sebagian kecil masyarakat juga menerima bantuan alat pengolahan singkong menjadi rasi. Secara distribusi, mayoritas masyarakat secara partisipasi berada pada tahap Tokenisme yaitu sebagian menentukan 
sendiri dalam hal distribusi dan sebagian lain berkonsultasi secara musyawarah bersama dengan anggota koperasi untuk masyarakat yang tergabung dalam koperasi Kampung Adat Cireundeu. Distribusi olahan pangan pokok singkong yang dilakukan oleh masyarakat Adat Cireundeu yaitu dengan menjual beberapa produk olahan dari singkong. Sebagian masyarakat ini tidak memiliki kerjasama dengan pihak manapun, karenabiasanya hanya menjual kepada wisatawan, ke pasar, atau kepada masyarakat setempat yang tidak memiliki persediaan beras singkong dan atau komoditas lain. Masyarakat yang menjual hasil olahan singkong secara perorangan berarti secara mandiri menentukan harga dan kontrol dalam distribusi atau penjualan bahan pangan singkong

Kedaulatan pangan distribusi produk olahan pangan dapat dilihat juga dari kontrol dari masyarakatnya sendiri. Sebagian dari responden mengatakan bahwa masyarakat memiliki kontrol terhadap pendistribusian bahan pangan pokok singkong juga. Hal ini dibuktikan dengan adanya koperasi yang terletak di samping Bale Sarasehan Kampung Adat Cireundeu. Beberapa masyarakat telah bekerja sama dengan koperasi mengenai pendistribusian dan penjualan hasil olahan pangan pokok singkong. Selain rasi, produk olahan singkong yang dikelola oleh koperasi ini tersebut antara lain dendeng kulit singkong, egg roll, cheese tic, dan aneka jenis kerupuk lainnya.

Sisi lain dalam hal penyimpanan dan distribusi hasil produksi adalah hasil produksi yang pada hal ini dilihat dari pemanfaatan seluruh bagian singkong dan pemanfaatan limbah singkong yang dilakukan oleh masyarakat Kampung Adat Cireundeu. Selama ini, masyarakat telah memanfaatkan seluruh bagian dari budidaya singkong, mulai dari daun, batang, umbi, kulit singkong, hingga ampas perasan singkong. Masyarakat mendapat pengetahuan mengenai pemanfaatan limbah singkong dan pembuatan produk olahan singkong lainnya dari berbagai pihak seperti dari leluhur, pemerintah, atau bahkan kalangan akademisi. Ketiga adalah kedaulatan pangan pada pilihan konsumsi pangan yang mayoritas masyarakatnya berada pada kategori Sedang. Menurut hasil penelitian, sebagian besar masyarakat memiliki kewenangan terhadap pilihan pangan konsumsi untuk komoditas singkong dan komoditas lain secara Partisipasi Aktif, sedangakan pada aspek praktik pemenuhan elemen kedaulatan pangan berada pada kategori Sedang. Selama ini masyarakat tidak diwajibkan mengonsumsi rasi pada rumah tangganya walaupun mengonsumsi rasi adalah tradisi kampung adat Cireundeu. Masyarakat secara bebas dapat menentukan pilihan pangan pokok sehari-harinya. Salah satunya dalam satu rumah tangga terdapat perbedaan dalam pangan pokok antara suami (rasi) dan istri (beras padi). Tidak terdapat pengaruh dari pihak luar yang mengatur pilihan konsumsi pangan masyarakat Kampung Adat Cireundeu. Masyarakat mengonsumsi pangan pokok setiap hari untuk komoditas singkong. Akan tetapi, masih banyak juga masyarakat yang masih mengonsumsi rasi karena mereka secara sadar bahwa tradisi yang telah dilakukan selama 100 tahun ini harus dilestarikan. Terakhir adalah kedaulatan pangan akan pengelolaan pengetahuan dan pematenan benih yang berada pada kategori Sedang dengan aspek kewenangan dalam kategori Partisipasi Aktif atau memiliki kewenangan penuh dan praktik pemenuhan elemen pangan pada kategori Sedang.

Masyarakat memiliki kebebasan dalam melakukan pengajaran atas budidaya pertanian mereka, tidak ada pihak lain yang memaksakan harus mengajarkan kepada masyarakat lain. Akan tetapi secara praktiknya, sebagian masyarakat tidak mengajarkan budidaya pertanian kepada masyarakat Kampung Adat Cireundeu karena masyarakat yakin bahwa seluruh masyarakat Adat Cireundeu telah mengetahui cara dan sistem budidaya singkong dan komoditas lain. Namun, terdapat beberapa masyarakat masih mengajarkan budidaya singkong, biasanya kepada anak-anak mereka yang memiliki keinginan terhadap pertanian singkong dari budidaya hingga pengolahannya.

Pertanian akan semakin berkelanjutan ketika ditanami dengan tanaman yang sesuai dengan kondisi wilayah setempat, sama seperti dengan Kampung Adat Cireundeu yang hingga sampai saat ini masih menggunakan benih lokal. Selama ini, tingkat kewenangan masyarakat berada pada tahap konsultasi atau tokenisme, hal ini karena masyarakat berkonsultasi mengenai komoditas singkong sesuai dengan jenis singkong yang cocok ditanam di wilayah Kampung Adat Cireundeu. Beberapa kali masyarakat dianjurkan untuk mencoba jenis singkong lain dari pemerintah (penyuluh pertanian), akan tetapi setelah masyarakat mencoba jenis singkong yang disarankan oleh pemerintah, dan pada akhirnya masyarakat tetap kembali kepada jenis singkong yang dulu. Jenis singkong yang saat ini banyak 
dibudidayakan oleh masyarakat Adat Cireundeu yaitu jenis singkong Garnawis. Singkong jenis ini lebih bertahan dan rasa singkongnya lebih enak dari yang sebelumnya.

Salah satu variabel dalam mewujudkan kedaulatan pangan menurut Saleh (2011) adalah melindungi benih dari pematenan. Perlu adanya perlindungan akan benih lokal dari tindakan pematenan oleh suatu pihak yang dapat memonopoli atas benih tersebut sehingga harga benih akan lebih mahal. Pematenan ini dikhawatirkan akan merugikan masyarakat setempat yang telah menggunakan benih tersebut sejak zaman nenek moyang mereka. Hingga sampai saat ini, di Kampung Adat Cireundeu tidak ada suatu pihak yang mencoba untuk mematenkan benih singkong yang menjadi ikon dari Kampung Adat Cireundeu, hanya saja terkadang pemerintah mencoba untuk membantu masyarakat dalam penggantian varietas singkong dalam budidayanya. Pemerintah telah beberapa kali mencoba beberapa varietas baru dengan harapan dapat membantu masyarakat dalam perbaikan produksi rasi. Akan tetapi, pada akhirnya masyarakat tetap kembali beralih ke varietas awal yaitu singkong Karikil dan Garnawis.

\section{Tingkat Rasa Memiliki Komunitas Kampung Adat Cireundeu}

Suatu komunitas di suatu wilayah akan terus bertahan jika antar anggotanya memiliki keinginan untuk mempertahankannya. Salah satu faktor yang dapat melihat hal tersebut yaitu jika anggota tersebut memiliki ikatan hubungan emosional yang disebut rasa memiliki komunitas. Suatu ikatan emosional di antara mereka tersebut bertujuan untuk berbagi kebutuhan mereka dan saling memenuhi satu sama lain.

Tabel 2 Jumlah dan persentase responden berdasarkan tingkat rasa memiliki komunitas Kampung Adat Cireundeu, 2018

\begin{tabular}{lrr}
\hline $\begin{array}{c}\text { Tingkat } \\
\text { Rasa } \\
\text { Memiliki }\end{array}$ & $\begin{array}{c}\text { Jumlah } \\
\text { (Orang) }\end{array}$ & $\begin{array}{c}\text { Persentase } \\
(\%)\end{array}$ \\
Komunitas & & \\
\hline Lemah & 0 & 0.00 \\
Sedang & 2 & 6.67 \\
Kuat & 28 & 93.33 \\
\hline Total & 30 & 100.00 \\
\hline
\end{tabular}

Berdasarkan Tabel 2 menunjukkan bahwa sebanyak 93.33\% responden memiliki dalam kategori Kuat untuk tingkat rasa memiliki komunitas. Data menggambarkan bahwa sebagian besar responden mengaku bahwa masyarakat memiliki ikatan yang kuat antar anggota komunitasnya dan akan terus dapat memenuhi kebutuhannya jika terus bersama sebagai satu komunitas.

Seseorang dikatakan memiliki rasa memiliki komunitas yang kuat ketika mereka sangat merasakan perasaan yang kuat pada komunitasmya berdasarkan keanggotaan, pengaruh, Integrasi dan pemenuhan kebutuhan, dan berbagi hubungan emosional dengan anggota lain dalam komunitas. Keempat indikator dalam memiliki rasa komunitas ini yang paling tinggi menyumbang kuatnya rasa memiliki komunitas adalah indikator sebagai anggota, kemudian disusul oleh integrasi dan pemenuhan kebutuhan, pengaruh, dan berbagi hubungan emosional.

Pertama, indikator Keanggotaan yang dimaksud dalam penelitian ini adalah perasaan bahwa seseorang telah mengabdikan dirinya untuk menjadi anggota dalam sebuah komunitas. Sebanyak $90 \%$ responden berada pada kategori Kuat dalam indikator keanggotaan. Berdasarkan sejarah yang dituturkan informan sekaligus responden, komunitas ini yang dibangun dari kekerabatan antarresponden yang memiliki hubungan keluarga antar responden dalam Komunitas Adat Cireundeu. Hal ini dapat mendorong semakin mengenalnya mereka dan identifikasi mereka sebagai satu keanggotaan dalam komunitas di Kampung Adat Cireundeu. Perasaan menjadi anggota pada Kampung Adat Cireundeu memiliki penilaian yang kuat hal ini karena masyarakat kampung adat ini jarang yang keluar dan tinggal di luar dari adat. Oleh sebab itu, masyarakat masih banyak yang memegang teguh 
aturan adat yang telah diwariskan oleh leluhur mereka dan mengajarkannya kepada anak cucu mereka mengenai makna-makna yang terkandung didalam kehidupan bermasyarakat di wilayah Kampung Adat Cireundeu. Rasa menjadi bagian dari Kampung Adat Cireundeu ditunjukan juga dengan rasa saling percaya dengan masyarakat lain bahwa kehidupan di kampung ini selalu damai dan tidak ada perselisihan.

Seseorang yang telah merasa bahwa dirinya menjadi bagian dari komunitas, pastinya memiliki simbol ataupun tanda yang sama sebagai identitas. Identitas ini yang menjadi salah satu kebanggaan akan menjadi bagian dari komunitas tersebut. Kampung Adat Cireundeu memiliki simbol dan tanda yang sama yang dimiliki oleh seluruh masyarakat adat yaitu untuk laki laki Baju hitam (Pangsi) dan ikat kepala, sedangkan untuk perempuan menggunakan kebaya putih. Penggunaan simbol dan tanda yang sama ini dilakukan ketika kampung ini memiliki upacara adat yang diselenggarakan, seperti upacara pernikahan ataupun sereh tahun. Spesialnya, tanda dan simbol ini tidak hanya dimiliki oleh masyarakat Kampung Adat Cireundeu saja, namun masyarakat muslim yang berada didalam lingkungan Kampung Adat Cireundeu juga memiliki tanda dan simbol yang sama. Hal ini berarti bahwa kehidupan di lingkungan masyarakat Kampung Adat Cireundeu ini memiliki rasa menjadi anggota dan rasa mempercayai antar anggota komunitas tinggi.

Kedua, indikator pengaruh dalam penelitian ini yaitu kekuatan yang dimiliki individu untuk mempengaruhi anggota lain dan kekuatan komunitas untuk mempengaruhi individu. Responden dalam penelitian ini sebagian besar berada dalam kategori Tinggi untuk rasa menjadi anggota (pengaruh). Setiap lapisan Masyarakat Kampung Adat Cireundeu memiliki perannya masing-masing. Mereka bekerja sama antar warga dalam menjalankan suatu kegiatan. Lapisan Pemuda (nom-noman) adat biasanya memiliki peran sebagai pelestari budaya yang menemani sekaligus memperkenalkan para wisatawan yang datang untuk mengetahui berapa hal penting dari Kampung Adat Cireundeu, sedangkan lapisan masyarakat lain membantu dalam kegiatan adat seperti pembangunan rumah adat (julang ngapak), upacara adat, maupun kegiatan lain yang berhubungan dengan adat.

Masyarakat Kampung Adat Cireundeu yang memiliki toleransi tinggi ini diwujudkan dengan keikutsertaannya dalam setiap kegiatan adat yang diselenggarakannya. Keikutsertaan dalam pelaksanaan kegiatan adat di Kampung Adat Cireundeu dilakukan secara kerja sama antar warga, segala persiapannya dilakukan secara bersama-sama dengan jangka waktu yang cukup lama sehingga ketika pelaksanaan kegiatan berjalan dengan lancar dan baik. Hal ini disebabkan karena masyarakat merasa memiliki kedekatan antar warga Cireundeu dan merasa bahwa kegiatan yang akan dilaksanakan harus diketahui prosesnya sehingga persiapan pelaksanaan mereka lakukan dengan senang hati. Proses pengambilan keputusan baik dalam pelaksanaan kegiatan adat maupun permasalahan lain dalam adat dilakukan secara mufakat dan musyawarah oleh masyarakat adat bukan dari tokoh adat. Adanya tokoh adat yang berada dalam kelembagaan adat seperti sesepuh adat, ais pangampih, dan ais paniten, tidak menjadi penentu dalam pengambilan keputusan adat. Masyarakat adat menjadi penentu dalam pengambilan keputusan. Setiap permasalahan yang perlu diselesaikan juga diputuskan secara bersama-sama oleh warga adat.

Ketiga yaitu integrasi dan pemenuhan kebutuhan, yang dimaksud dalam penelitian ini adalah perasaan responden bahwa kebutuhan anggota akan dipenuhi oleh sumberdaya yang diterima melalui keanggotaan mereka dalam kelompok. Indikator ini merupakan yang paling kuat berkontribusi terhadap rasa memiliki komunitas adat ini. Masyarakat menyatakan senang dengan menjadi bagian dari komunitas Kampung Adat Cireundeu di kawasan perbukitan dengan komoditas pertanian utama singkong masyarakat memiliki perasaan kuat untuk menghargai kemampuan komunitas ini dalam menyelenggarakan kegiatan melalui kelembagaan pangan untuk memenuhi kebutuhan pangan utama singkong ini. Masyarakat juga sangat merasakan selama tinggal di Kampung Adat Cireundeu, kebutuhan akan pangan dan spiritual mereka terpenuhi. Kebutuhan spritual yang dimaksud adalah mengenai sistem kepercayaan mereka "sunda wiwitan" yang didukung dengan seringnya interaksi antar warga, pengajaran spiritual kepada anak- anak mereka, dan ditambah dengan kegiatan adat seperti kegiatan sereh tahun yang dilaksanakan setahun sekali. Kebutuhan soal pangan juga terpenuhi 
semenjak masyarakat adat menjadi warga adat. Kebutuhan ini disebebkan oleh kesamaan masyarakat adat akan kebiasaan mengonsumsi beras singkong sejak lahir.

Kegiatan upacara sereh tahun yang diadakan setiap tahun ini memiliki efek kepada masyarakat sekitar baik masyarakat adat maupun non adat. Pelaksanaan upacara ini menjadi daya tarik wisatawan untuk datang menyaksikan secara langsung tradisi mereka, sehingga hal ini menjadi peluang bagi masyarakat untuk menjajakan berbagai barang dagang kepada wisatawan. Hal ini berarti masyarakat memiliki kemajuan bagi masyarakatnya

Indikator yang terakhir dalam menggambarkan rasa memiliki komuniyas adalah berbagi pengalaman emosional. Berbagi pengalaman emosional yang dimaksud adalah hubungan emosional bersama dalam suatu komunitas yang terbentuk dari interaksi positif, saling berbagi cerita dan pengalaman yang dilakukan bersama. Semakin banyak orang berinteraksi, maka semakin besar kemungkinan mereka membentuk hubungan yang erat, yang kemudian mengarah keikatan yang lebih kuat. Responden dalam penelitian ini sebagian besar berada dalam kategori Kuat untuk berbagi pengalaman emosional.

Kuatnya pada indikator ini karena masyarakat telah nyaman dengan kehidupan yang rukun dan tentram antar warganya di kampung ada ini. Masyarakat selama tinggal di kampung ini tidak pernah merasakan konflik antar warga, baik sesama masyarakat adat maupun dengan warga msulim. Selain itu nilai-nilai yang diajarkan oleh orang tua atau leluhur mereka sangat melekat pada masyarakat ini. Nilai nilai ini berkaitan dengan hubungan antar manusia-Tuhan Sang Pencipta, manusia-manusia, dan manusia-alam, semua harus berjalan seimbang dan saling mendukung.

Kehidupan yang rukun antar warga membuat masyarakat sendiri merasa senang dan menikmati ketika sedang bertemu dan berkumpul bersama. Penyelenggaraan kegiatan adat yang sering dilakukan oleh masyarakat adat, biasanya masyarakat melakukan secara bersama-sama dan sukarela, biasanya mereka menyebutkan hal ini dengan "Korpe". Korpe merupakan kegiatan yang bersifat sukarela ini dilakukan oleh masyarakat Kampung Adat Cireundeu baik oleh masyarakat adat sendiri maupun masyarakat muslim. Biasanya masyarakat saling membantu dalam persiapan kegiatannya. Tidak hanya bapak-bapak yang turut hadir dalam kegiatan korpe ini, akan tetapi ibu-ibu juga turut membantu dalam pelaksanaannya, seperti membantu menyiapkan konsumsi untuk kegiatan korpe. Prestasi yang telah diperoleh oleh Kampung Adat Cireundeu semakin dikenal oleh masyarakat umum dan hampir setiap pekan, Kampung Adat Cireundeu selalu dikunjungi dari kalangan masyarakat luar, akademisi, maupun dari instansi pemerintah, baik lokal maupun manca negara. Harapan dari pemerintah untuk kedepan, Kampung Adat Cireundeu memiliki pengelolaan atas kawasan Kampung Adat Cireundeu dengan konsep sama seperti Desa Wisata yang memiliki pengelolaan sumberdaya alam dan manusia yang baik termasuk dalam penyediaan penginapan maupun kegiatan kunjungan.

\section{Validasi Konstruk Rasa memiliki Komunitas dengan Kedaulatan Pangan}

Uji validitas identifikasi konstruk dengan uji hubungan Rank Spearman antara rasa memiliki komunitas dengan kedaulatan pangan menunjukkan bahwa kedua variabel tersebut tidak berhubungan yang ditandai dengan nilai $\alpha>0.05$ (Tabel 3). Nilai koefisien korelasi yang sebesar $0.115(\alpha>0.05)$ menunjukkan hubungan yang sangat lemah dan tidak signifikan. 
Tabel 3 Jumlah dan persentase responden berdasarkan tingkat rasa memiliki komunitas Kampung Adat Cireundeu, 2018

\begin{tabular}{cccc}
\hline Tingkat & \multicolumn{3}{c}{ Tingkat Kedaulatan Pangan } \\
\cline { 2 - 4 } Rasa & & Praktek \\
Memiliki & Kewenangan & $\begin{array}{c}\text { pemenuhan } \\
\text { Elemen }\end{array}$ & Total \\
Komunitas & & 0.062 & $\mathbf{0 . 1 1 5}$ \\
$\rho$-value & 0.171 & 0.745 & 0.546 \\
$\alpha$ & 0.367 & & \\
\hline
\end{tabular}

Hasil uji validitas dengan korelasi juga menunjukkan bahwa rasa memiliki komunitas dan tingkat kedaulatan pangan tidak memiliki hubungan yang signifikan baik terhadap tingkat kedaulatan pangan kewenangan, praktek pemenuhan elemen kedaulatan pangan. Pada uji korelasi tingkat rasa memiliki komunitas dengan tingkat kedaulatan pangan kewenangan dan praktek pemenuhan elemen kedaulatan pangan memiliki nilai 0.171 dan $0,062(\alpha>0.05)$ yang berarti juga memiliki hubungan yang sangat lemah dan tidak signifikan.

Ketidakhubungan kedua variabel ini dapat mengkonfirmasi kerangka konseptual yang sudah dibangun sebelumnya bahwa rasa memiliki komunitas bekerja di tingkat individu anggota komunitas dan belum mempengaruhi besarnya tingkat kewenangan dan praktek pemenuhan elemen kedaulatan pangan. Meskipun demikian, koefisien korelasi antara kedua variabel tersebut yang menunjukkan nilai yang positif namun tidak signifikan membuktikan bahwa kedua variabel tersebut tidak berhubungan dengan kuat. Data tersebut menunjukkan bahwa adanya faktor lain dalam rumah tangga di komunitas Adat Cireundeu yang mempengaruhi kewenangan dan perilaku pemenuhan elemen kedaulatan pangan, seperti (1) kebijakan, (2) internalisasi rasa memiliki komunitas ke perilaku; dan (3) karakteristik komunitasnya. Pertama, kebijakan pemerintah atau komunitas yang memiliki pengaturan dalam elemen produksi, penyimpanan dan distribusi hasil, pilihan konsumsi pangan, dan pengelolaan pengetahuan dan pematenan benih.

Faktor kedua yang diduga dapat menyebabkan hubungan yang tidak signifikan antara rasa memiliki komunitas dan kedaulatan pangan adalah bahwa ikatan anggota komunitas pada komunitasnya belum menjadi perilaku untuk kedaulatan pangan. Hal ini sejalan dengan Adriana et al. (2017) yang menyatakan bahwa apa yang dirasakan pada komunitas belum tentu tercermin pada kehidupan seharihari dan diketahui bahwa aksi kolektif hanya terdapat pada kegiatan yang mendukung fasilitas umum. Hal ini berarti rasa memiliki komunitas yang dimiliki anggota komunitas Adat Cireundeu meskipun kuat namun belum dapat mempengaruhi secara langsung perilaku kolektif komunitas dalam elemen berdaulat pangan.

Faktor ketiga yaitu karakter masyarakat Kampung Adat Cireundeu yang termasuk ke dalam komunitas adat sudah yang tampaknya memiliki rasa memiliki komunitas yang kuat pada setiap anggota komunitasnya untuk terlibat dalam kelembagaan pangan. Namun hal ini dari aspek pengukuran dapat menyebabkan variasi nilai variabel tersebut menjadi homogen sehingga menyebabkan tidak signifikannya pengaruh variabel tersebut pada kedaulatan pangan. Pada komunitas lain yang karakter komunitasnya lebih heterogen, rasa memiliki komunitas akan lebih memiliki variasi nilai sehingga secara statistik akan lebih dapat berhubungan dengan aksi kolektif di komunitas tersebut. Padahal kekuatan rasa memiliki pada komunitas meskipun pada individu akan dapat mendorongnya memunculkan aksi kolektif, yang dalam hal ini dikaji melalui kewenangan dan praktek pemenuhan elemen kedaulatan pangan. 


\section{KESIMPULAN}

Kesimpulan yang dapat ditarik berdasarkan hasil dan pembahasan penelitian ini adalah sebagai berikut: (1) Tingkat kedaulatan pangan masyarakat Kampung Adat Cireundeu termasuk Sedang yang terdiri dari tingkat kewenangan yang berada pada tingkat Tokenisme dan praktek pemenuhan elemen kedaulatan pangan yang Sedang; (2) Kewenangan yang dimiliki masyarakat Kampung Adat Ciruendeu dapat dilihat pada 4 (empat) elemen kedaulatan pangan yang terdiri atas (a) produksi pertanian. (b) Penyimpanan dan distribusi hasil produski. (c) Pilihan pangan konsumsi, dan (d) Pengelolaan pengetahuan dan pematenan benih. Keempat indikator tersebut sebagian besar berada pada kategori Partisipasi Aktif, kecuali pada aspek produksi yang berada pada kategori Tokenisme; (3) Praktek pemenuhan elemen kedaulatan pangan masyarakat Kampung Adat Ciruendeu secara umum berada pada kategori Sedang. Hal ini dapat dilihat pada 4 (empat) elemen kedaulatan pangan yang terdiri atas (a) produksi pertanian. (b) Penyimpanan dan distribusi hasil produski. (c) Pilihan pangan konsumsi, dan (d) Pengelolaan pengetahuan dan pematenan benih; (4) Tingkat karakteristik komunitas masyarakat Kampung Adat Cireundeu yang dilihat pada rasa memiliki komunitas berada pada kategori Tinggi baik dari indikator keanggotaan, pengaruh, integrasi dan pemenuhan kebutuhan, serta berbagi pengalaman emosional; dan (5) Hasil uji validasi identifikasi konstruk rasa memiliki komunitas tidak memiliki hubungan dengan kedaulatan pangan.

\section{Saran}

Berdasarkan hasil penelitian yang telah dilakukan, saran yang dapat diberikan dan dijadikan masukan sebagai bahan pertimbangan bagi pihak pihak terkait yaitu: (1) Perlu dilakukan penelitian lebih lanjut mengenai tingkat kedaulatan pangan, karena selama ini, konsep kedaulatan masih terbuka dan masih belum terdapat variabel baku dalam mengukur kedaulatan pangan tingkat rumah tangga dan tingkat negara; dan (2) Perlunya mengkaji lebih lanjut mengenai peran pemerintah dalam mewujudkan kedaulatan pangan masyarakat pada Kampung Adat Cireundeu.

\section{DAFTAR PUSTAKA}

Adriana, G., Nurmala K. P., Arya H. D. 2017. Kohesivitas Komunitas Nelayan Dalam Menghadapi Perubahan Iklim Di Pesisir Jawa Barat (Studi Kasus: Di Pedesaan Jawa Barat). Sodality: Jurnal Sosiologi Pedesaan. April 2017, hal 67-74 | 69

Anastasi, A., Susana, U. 1997. Psychological Testing (7th ed.). Upper Saddle River, NJ: PrenticeHall, Inc.

[BKPD] Badan Ketahanan Pangan Daerah. 2013. Statistika Ketahanan Pangan Jawa Barat Tahun 2013 [Internet]. [diunduh 2018 Mei 06]. Tersedia pada: http://dkpp.jabarprov.go.id/wpcontent/uploads/2017/03/DATA-STATISTIK-20131.pdf

Duadji N. 2013. Partisipasi Publik dalam Pengambilan Keputusan Anggaran Pendapatan dan Belanja Daerah (APBD) Provinsi Lampung. J Bina Praja. [Internet]. 5 (3): 197 - 204. [diunduh 2018 Feb 21]. Tersedia pada: http://binaprajajournal.com/ojs/index.php/jbp/article/view/112

Effemdi S, Tukiran. 2012. Metode Penelitian Survei. Jakarta (ID):LP3ES

Falatehan SF. 2017. Pendekatan Psikologi Komunitas dalam Memprediksi Peranan Rasa Memiliki Komunitas Terhadap Munculnya Partisipasi Masyarakat. Jurnal Ilmiah Psikologi Manasa [Internet]. 6 (1): 66-90. [diunduh 2018 Feb 21]. Tersedia pada: http://ojs.atmajaya.ac.id/index.php/manasa/article/view/628/495

Gulo W. 2002. Metode Penelitian. Jakarta (ID): Gramedia Widiasarana Indonesia. 
Indraningsih K S. 2013. Perspektif Kelembagaan Lumbung Pangan Non Beras dalam Mendukung Kedaulatan Pangan Lokal. Prosiding Seminar Nasional Hari Pangan Sedunia Ke-33 "Optimalisasi Sumberdaya Lokal Melalui Diversifikasi Pangan Menuju Kemandirian Pangan dan Perbaikan Gizi Masyarakat Menyongsong Masyarakat Ekonomi ASEAN 2015". Bagian pengembangan infrastruktur dan Kelembagaan Pertanian. No 1. [diunduh 2018 Feb 21]. Tersedia http://pse.litbang.pertanian.go.id/ind/pdffiles/PROS2013_C1_Kurnia\%20Suci.pdf

pada:

Khusairi A, Yuli N, Alifah NM. 2017. Sense of Community dan Partisipasi Warga Kampung wisata Jodipan. Jurnal RAP UNP [internet]. [diunduh 2018 Maret 22]. 8(01): 1-12. Tersedia pada: http://ejournal.unp.ac.id/index.php/psikologi/article/view/7947/6066

Kompas.com. 2013. Banyak yang Tidak Paham soal Kedaulatan Pangan diunduh dari https://ekonomi.kompas.com

McMillan D W, David M C. 1986. Sense of Community: A Definition and Theory. Journal of Community Phycology [internet]. [diunduh 2018 Maret 22]. 14: 95-109. Tersedia pada: https://pdfs.semanticscholar.org/e5fb/8ece108aec36714ee413876e61b0510e7c80.pdf

Nasdian F T. 2014. Pengembangan Masyarakat. Bogor (ID): Pustaka Obor.

Nugrahayuningtyas A. 2017. Peran Gender dalam Perekonomian Rumah Tangga Petani pada Masyarakat Adat [Skripsi]. Bogor (ID): Institut Pertanian Bogor.

Saleh R. 2011. Struktur Penguasaan Tanah Masyarakat dan Upaya Membangun Kedaulatan pangan [Skripsi]. Bogor (ID): Institut Pertanian Bogor.

Singarimbun M, Effendi S. 1989. Metode Penelitian Survai. Jakarta (ID): LP3ES.

Siregar B. 2002. Kembali ke Akar: Kembali ke Konsep Otonimi Masyarakat Asli. Jakarta (ID): Forum Pengembangan Partisipasi Masyarakat

Sumardjo. 2003. Kepemimpinan dan Pengembangan Kelembagaan Pedesaan: Kasus Kelembagaan Ketahanan Pangan. Bogor [ID]: Bogor Press.

Suharsaputra U. 2012. Metode Penelitian: Kuantitatif, Kualitatif, dan Tindakan. Bandung (ID): Refika Aditama

Syahyuti, Sunarsih, Sri W, Wahyuning K. Sejati, Miftahul A. 2015. Paradigma Kedaulatan Pangan dan Keterlibatan Swasta: Ancaman terhadap Pendekatan Ketahanan Pangan. Jurnal Forum Penelitian Agro Ekonomi [internet]. [diunduh 2017 Sept 07]; 33(03): 95-109. Tersedia pada: http://ejurnal.litbang.pertanian.go.id/index.php/fae/article/view/3792/3141

Tishaeni H. 2010. Keberlanjutan Komunitas Adat Kampung Cireundeu Kelurahan Leuwigajah Kecamatan Cimahi Selatan Kota Cimahi [Skripsi]. Bogor (ID): Institut Pertanian Bogor.

[UU] Undang-Undang Nomor 18 Tahun 2012 Tentang Pangan. [Internet]. [diunduh 2018 Feb 21]. Tersedia pada: https://luk.staff.ugm.ac.id/atur/UU18-2012Pangan.pdf

Yuniarti Adia. 2013. Persepsi, Keberlanjutan Kelembagaan, dan Efektivitas Program CSR PT Pertamina Gas di Desa Permisan Kabupatena Sidoarjo [Skripsi]. Bogor (ID): Institut Pertanian Bogor.

Yuwono T, Sri W, Dwidjono H D, Masyhuri, Didik I, Susamto S, Sunarru S H. 2011. Pembangunan Pertanian: Membangun Kedaulatan Pangan. Yogyakarta (ID): UGM Press. 